\title{
Some Observations on Unfree Labour, Capitalist Restructuring, and Deproletarianization ${ }^{1}$
}

\section{TOM BRASS}

Both historically and actually, there is a complex interrelationship between the existence of unfree labour and the process of class formation and struggle in the course of agrarian transformation. However, much current writing about rural labour in the Third World is based on three interrelated assumptions. First, that labour market imperfections are always the fault of peasants resisting the attempts of capital to proletarianize them; second, that capitalist penetration of agriculture always transforms peasants into proletarians, in the full meaning of the latter term; and third, that where these exist (non-urban contexts, backward agriculture, and/or underdeveloped countries), unfree relations are always unproblematically pre-capitalist forms of production destined to be eliminated in the course of this process. In the marxist approach which follows, it will be argued that each of these three assumptions is wrong.

Conversely, it will be suggested here that capitalism is not only compatible with unfree labour but in certain situations actually prefers this to a free workforce; accordingly, the interrelationship between free and unfree labour, and in particular the process of deproletarianization, is determined both historically and contemporaneously by class struggle (waged from above as well as from below). In support of this view it will be necessary to confront two interrelated revisionist interpretations of unfree production relations: on the one hand neoclassical economic theory, and on the other the "culturalist" arguments derived from moral economy, survival strategies and resistance theory, (re-)interpretations which involve either a denial or a dilution of unfree labour. Faced with the coexistence of unfreedom and capitalist production, yet unable to theorize the connection between them, one particular variant of marxism (the semi-feudal thesis) is in some senses a mirror image of revisionism. The latter accepts the presence of capitalism, and accordingly redefines unfree relations of production as a form of free wage labour; the former, by contrast, accepts the presence of unfreedom, but redefines the mode of production itself as feudal or semi-feudal.

\section{MARXISM, CAPITALISM, AND UNFREE LABOUR}

Any definition of what constitutes an unfree production relation has to begin by focusing on the labour-power of the subject as private property,

I The writer wishes to thank Henry Bernstein for a stimulating discussion of some of the theoretical issues raised in section 1.

International Review of Social History 39 (1994), pp. 255-275 
and hence as an actual/potential commodity over which its owner has disposition. ${ }^{2}$ Unlike a free labourer, who is able to enter or withdraw from the labour market at will, due to the operation of ideological constraints or extra-economic coercion an unfree worker is unable personally to sell his or her own labour-power (in other words, to commodify it), regardless of whether this applies to employment that is either of time-specific duration (e.g. contract work, convict labour, indentured labour) or of an indefinite duration (chattel slavery).

- For many writers on the subject, the unfreedom inherent in chattel slavery derives from property rights exercised by one person over another. All forms of work relationship that do not entail ownership of persons are consequently regarded as free. Such a view, however, overlooks additional forms of unfreedom which occur in situations where the labouring subject is prevented from entering the labour market under any circumstances (in which case labour-power ceases to be a commodity), is prevented from entering the labour market in person (labour-power remaining a commodity in such circumstances, but is sold by someone other than its owner), and is permitted to enter the labour-market in person, but only with the consent and at the convenience of someone other than its owner. It is precisely these kinds of unfreedom which arise in the case of convict, bonded, contract and indentured labour. ${ }^{3}$

2 A number of important issues relating to the theorization of unfreedom in different historicalgeographical contexts cannot be covered here. These include questions of methodology (the nature of the written and/or historical record, the methodological accessibility of coercion, the enforcement of debt-servicing labour obligations by means of indirect pressure exercised through actual/fictive kinship and caste networks, etc.) and theory (non-economic concepts of unfreedom, defined in terms of fraud/deception/trickery, maltreatment), all of which are addressed elsewhere. Tom Brass, "Coffee and Rural Proletarianization: A Comment on Bergad", Journal of Latin American Studies, 16 (1984), pp. 143-152; "Free and Unfree Rural Labour in Puerto Rico during the Nineteenth Century", Journal of Latin American Studies, 18 (1986), pp. 181-193; "The Elementary Strictures of Kinship: Unfree Relations and the Production of Commodities', Social Analysis, 20 (1986), pp. 56-68; "Unfree Labour and Capitalist Restructuring in the Agrarian Sector: Peru and India", Journal of Peasant Studies, 14 (1986), pp. 50-77; "Slavery Now: Unfree Labour and Modern Capitalism", Slavery and Abolition, 9 (1988), pp. 183-197; "The Latin American Enganche System: Some Revisionist Reinterpretations Revisited", Slavery and Abolition, 11 (1990), pp. 74-103; "Class Struggle and the Deproletarianization of Agricultural Labour in Haryana (India)". Joumal of Peasant Studies, 18 (1990), pp. 36-67; "Market Essentialism and the Impermissibility of Unfree Labour", Slavery and Abolition, 12 (1991), pp, 225-244; and Tom Brass and Henry Bernstein, "Proletarianization and Deproletarianization on the Colonial Plantation", Journal of Peasant Studies, 19 (1992), pp. 1-40.

${ }^{3}$ Needless to say, the conceptual extension of unfreedom to include labour relations other than slavery is contraversial, and the subject of much debate. For more recent attempts to define unfree labour, see Robert Miles, Capitalism and Unfree Labour: Anomaly or Necessity? (London, 1987); and V. K. Ramachandran, Wage Labour and Unfreedom in Agriculture: An Indian Case Study (Oxford, 1990), ch. 8. 
Like chattel slavery, such relationships entail the loss on the part of a debtor and/or his or her kinsfolk of the right to sell their labour-power at prevailing free market rates during the period of bondage. Unlike chattel slavery, however, where the person of the slave is itself the subject of an economic transaction, in the case of a bonded, convict, contract or indentured labourer it is the latter's labour-power which is bought, sold, and controlled without the consent of its owner. Hence the frequent conflation of these arrangements with the free wage relation, notwithstanding the fact that while a free wage labourer may personally dispose of his or her own labour-power (by selling it to whomsoever s/he wishes, or withdrawing from the labour market altogether), neither a chattel slave nor a bonded/convict/contract/ indentured labourer possesses this right. All the latter may appear in the free labour market, therefore, but not as autonomous sellers of their own labour-power. ${ }^{4}$

The necessary starting-point for a consideration of the connection between unfreedom and capitalism is Marx's emphasis on the freedom of wage labour in the relationship between labour and capital, the social relation of production that constitutes the distinctive character of capitalism. As is well known, the designation of the freedom of wage labour has a double aspect: labouring subjects ("direct producers") are "freed" from access to the means of production that secure their reproduction, and consequently they are (and must be) free to exchange their labour-power with capital for wages with which to purchase subsistence. $^{5}$

Generally speaking, both aspects of wage labour capture the difference between capitalism and pre-capitalist modes of production. The first aspect signals the moment of dispossession of pre-capitalist producers, part of the process of primitive accumulation. Dispossession is the condition of the formation of a class of free wage labour which is the second aspect, or moment of proletarianization. The contrast here is that, whereas in pre-capitalist modes of production labour is exploited by means of extra-economic compulsion, under capitalism proletarians are owners of the commodity labour-power which they exchange with capital under the "dull compulsion of economic forces".

- It is important to distinguish between a free market in labour, in which both free and unfree labour-power can circulate, and a free labour market, in which only free wage labour circulates. A result of the failure to make this distinction is market essentialism (see below), a theoretical effect of which is the conflation of two relationally distinct transactions: on the one hand a direct exchange between worker and employer (labour-power as the private property of the individual subject), and on the other an indirect transaction involving only employers (or the latter and contractors), one of whom transfers an unfree worker to the other (private property in the labour-power of the individual subject). In the antebellum American South, for example, plantation slaves were no less such for being hired out by their owners, either to other planters or to manufacturing employers in local towns. Robert S. Starobin, Industrial Slavery in the Old South (New York, 1970), pp. 128-137.

' On this point, see Karl Marx, Capiral - Volume I (London, 1976), pp. 271-272. 
Having outlined these familiar positions, it is useful to interrogate them a little further. First, with regard to the moment of dispossession, it is necessary to recognize that not all social subjects in all pre-capitalist formations necessarily had property or usufruct rights in land and/or other means of production, let alone that all pre-capitalist formations guaranteed the means of subsistence. Historically, strongly differentiated pre-capitalist formations in Asia and Latin America have contained landless labourers "available" for recruitment by capitalism. ${ }^{6}$ In short, dispossession of pre-capitalist producers was not always necessary to the (initial) formation of a class of capitalist wage labour.

This brings us to the second, and more general, moment of proletarianization. This too has an important double aspect, albeit often overlooked or confused, that is conveyed theoretically in the distinction between labour-power and labour, and more concretely in the difference between labour market and labour process. Labour-power is the capacity to work that is the property of workers (their mental and physical energies): the commodity they exchange with capital for wages. Labour is the use value of labour-power: the expenditure of the mental and physical energies of workers in a production process controlled by capitalists, the products of which are the property of the latter and not the former. Correspondingly, the labour market designates the site in which labour-power is exchanged, and the labour process the site in which labour is exploited by the imperatives of capitalist production, accumulation, and profit. Evidently, both labour markets and labour processes within capitalism exhibit a wide range of variation in their specific conditions, how their contradictions are manifested, and the forms of class struggle to which they give rise.

What is the connection between on the one hand the theoretical rationale of the freedom of wage labour and on the other the pervasive incidence of unfree wage labour throughout the history of capitalism? Accordingly, two suggestions are made here. First, given this interconnectedness between accumulation and unfree labour, that in particular instances it might be more appropriate to invert the usual way in which the question is posed: that is, to problematize the achievement of free wage labour rather than the existence of unfreedom. And second, that

- On the pre-colonial/pre-capitalist presence and extent of landless labour in South India, see Dharma Kumar, Land and Caste in South India: Agricultural Labour in Madras Presidency in the Nineteenth Century (Cambridge, 1965); Benedicte Hjejle, "Slavery and Agricultural Bondage in South India in the Nineteenth Century", The Scandinavian Economic History Review, 15 (1967), pp. 71-126. For Asia generally, see Jan Breman, Labour Migration and Rural Transformation in Colonial Asia (Amsterdam, 1990). For the presence of an extensive "ambulatory" migrant workforce, composed of landless labour, in the Central Valley region of Chile from the mid-nineteenth century onwards, see Amold J. Bauer, Chilean Rural Society from the Spanish Conquest to 1930 (Cambridge, 1975). 
assaults by capital (actual or potential, pre-emptive or reactive) on the freedom of wage labour - the ability of workers to enter and withdraw from particular labour markets and labour processes - are a general feature of capitalism. ${ }^{7}$ That is, the capitalist class as a whole (or its representatives) in some cases, or particular groups and types of capitalists and/or individual capitalists in other cases, seek to define and -redefine the labouring subject so as to limit the exercise of his/her freedom as the owner of the commodity labour-power.

Such actions and struggles on the part of capital (with their economic, political and ideological expressions) aim to bring about deproletarianization, in the sense of diminishing or eliminating altogether the freedom of wage labour as defined above: the ability of owners of the commodity labour-power to exchange it as they choose (on which more, see below). In other words, it is precisely by means of deproletarianization that capital is able to effect a double dispossession of its workforce: both from the means of labour, and also from the means of commodifying labour-power itself. Moreover, the ability of capital to engineer unfreedom in labour markets - to impose restrictions in the process of recruiting workers - has implications for the freedom of capital in using workers in labour processes from which they are unable to withdraw. Evidently certain historical conditions, such as those of colonial imperialism, provide capital with reasons and opportunities for waging this particular kind of class struggle against labour. In this connection we should also note that the trajectories of wage labour are often marked by competition between branches or groups of capitalists and/ or individual capitalists for access to and control over labour-power.

On the side of workers, this suggests that their class struggle against capital is commonly a struggle to assert, reassert or extend their freedom to dispose of their own labour-power: either separately from or combined with class struggle to destroy capitalism, therefore, such actions always

' On this point, see texts by, inter alia, W. Kloosterboer, Involuntary Labour since the Abolition of Slavery (Leiden, 1960); Keith R. Authauser, "Slavery and Scientific Management", Joumal of Economic History, 33 (1973), pp. 811-824; Charles van Onselen, Chibaro: African Mine Labour in Southern Rhodesia 1900-1933 (London, 1976); Phillip Corrigan, "Feudal Relics or Capitalist Monuments? Notes on the Sociology of Unfree Labour", Sociology, 11 (1977), pp. 435-463; Martin Legassick, "Gold, Agriculture, and Secondary Industry in South Africa, 1885-1970; From Periphery to Sub-Metropole as a Forced Labour System", in R. Palmer and N. Parsons (eds), The Roots of Rural Poverty in Central and Southern Africa (London, 1977), pp. 175-200; Sudipto Mundle, Backwardness and Bondage: Agrarian Relations in a South Bihar District (New Delhi, 1979); Claude Meillassoux, Maidens, Meal and Money (Cambridge, 1981), pp. 91ff.; Utsa Patnaik, "Introduction", in Patnaik and Dingwaney, Chains of Servitude: Bondage and Slavery in India (Madras, 1985); Brass, "Unfree Labour and Capitalist Restructuring", and "Slavery Now": Miles, Capitalism and Unfree Labour; Robin Cohen, The New Helots: Mfigrants in the New International Division of Labour (Aldershot, 1987); A. Zegeye and S. Ishemo (eds), Forced Labour and Migration: Patterns of Movement within Africa (London, 1989). 
constitute a potential or actual threat to existing property relations. ${ }^{8}$ Accordingly, when workers seek to defend and exercise their freedom as owners of labour-power, they are also required to contest on an individual or collective basis the attempts by capital to impose/reimpose and reproduce unfreedom both in the labour market and the labour process. That the experience of the proletarian condition does not automatically generate an immediate, unambiguous or exclusive class consciousness on the part of workers, therefore, may in given circumstances be a consequence of the fact that the aim of deproletarianization is precisely to prevent, deflect or distort the development of just such a consciousness of class. For this reason, the experience of becoming a worker in the employ of capital, or the change from class-in-itself to class-for-itself, has crucial implications for the self-perception and the perception-of-others on the part of the labouring subject, as well as the forms taken by any resulting political action. Viewed thus, unfree relations of production are an integral part of both class struggle and capitalist accumulation in the context of much Third World agriculture.

\section{REVISIONIST CONCEPTS OF UNFREE LABOUR}

In contrast to the marxist interpretation outline above, of unfreedom as an exploitative relationship which permits the extraction of surplus labour, and which is either reconstituted or dissolved in the process of class struggle, the revisionist project which structures much recent writing on unfreedom eliminates the element of coercion from most or all agrarian relationships, and subsequently reclassifies them as free wage labour. Hence revisionist contributions to debates about rural labour theorize what marxists term unfreedom as a form of equal exchange, or a benign (and thus tension-free) arrangement to the benefit of all parties to the relation. ${ }^{9}$ Eschewing objective definitions, these

This applied in the case of the antebellum American South, for example, where the debates on slavery taking place during the 1840 s were structured by an underlying fear of a threat to property relations. Concerned that an emergent rural proletariat would ultimately demand the expropriation of the Southern landowning class, therefore, anti-abolitionists such as Cardozo and Dew advocated ruling class unity between Northern property owners and Southern planters in defence of slavery in order to counter a potential working-class challenge to existing property rights. Allen Kaufman, Capitalism, Slavery, and Republican Values: Antebellum Political Economists 1819-1848 (Austin, 1982), pp. $121 \mathrm{ff}$.

9 Texts which subscribe to this view include, inter alia, Suzanne Miers and Igor Kopytoff (eds), Slavery in Africa: Historical and Anthropological Perspectives (Madison, 1977); Arnold Bauer, "Rural Workers in Spanish America: Problems of Peonage and Oppression", Hispanic American Historical Review, 59 (1979), pp. 34-63; Daniel Cotlear, El sistema del Enganche del Siglo XX: una version diferente, Bachelor's Thesis in Economics, Universidad Católica del Perú (Lima, 1979); Harry E. Cross, "Debt Peonage Reconsidered: A Case Study in Nineteenth Century Zacatecas, Mexico", Business History Review, 53 
texts adopt subjective criteria when conceptualizing freedom/unfreedom, and consequently maintain that what outside observers wrongly interpret as unfree relations derives from the voluntary entry by rural labour into "reciprocal" and essentially desirable working arrangements which provide the labouring subject with economic security in the form of a "subsistence guarantee" or "employment insurance".10 Accordingly, revisionists theorize the debt component of relations such as indenture, peonage, contract or bonded labour as evidence not of the coercive power exercised by employers but much rather of the enhanced bargaining power exercised by workers. ${ }^{11}$.

Significantly, this revisionist view concerning unfree social relations of production is epistemologically no different from (and in some instances is explicitly determined by) neoclassical economic theory. ${ }^{12}$ Within such an economic framework, silence on the part of the choice-making subject is interpreted as assent: accordingly, a result of

(1979), pp. 473-495; Anthony Reid (ed.), Slavery, Bondage and Dependency in Southeast Asia (St Lucia, 1983); Pranab Bardhan, Land, Labor, and Rural Poverty (Delhi, 1984); Jan Breman, Of Peasants, Migrants and Paupers: Rural Labour Circulation and Capitalist Production in Western India (Delhi, 1985); Gillian Hart, Power, Labor, and Livelihood: Processes of Change in Rural Java (Berkeley, 1986); Gillian Hart, "Exclusionary Labour Arrangements: Interpreting Evidence on Employment Trends in Rural Java", Journal of Development Studies, 22 (1986), pp. 681-696; Alan Knight, "Mexican Peonage: What Was It and Why Was It?", Journal of Latin American Studies, 18 (1986), pp. 41-74; Lewis Taylor, "Earning a Living in Hualgayoc, 1870-1900", in Rory Miller (ed.), Region and Class in Modern Peruvian History (Liverpool, 1987), pp. 103-124; Alan Knight, "Debt Bondage in Latin America", in Lénie Archer (ed.), Slavery and Other Forms of Unfree Labour (London, 1988), pp. 102-117. For the way in which pro-slavery ideology in the antebellum American South projected unfreedom as beneficial to its subject ("positive good") and cast planter/slave relations in terms of "reciprocity", see J. A. Glickstein, Concepts of Free Labor in Antebellum America (New Haven, 1991); and L. E. Tise, Proslavery: A History of the Defense of Slavery in America, 1701-1840 (Athens, Georgia, 1987).

to Among those who interpret unfreedom as a form of "subsistence guarantee", "employment insurance", and/or "patronage" are Breman, Peasants, Migrants, pp. 127ff; Bardhan, Land, Labor, pp. 175-176; Bauer, "Rural Workers", pp. 44, 56, 62; Cotlear. El Sistema, pp. 37-39; Cross, "Debt Peonage", pp. 488, 490; Taylor, "Earning a Living", p. 112; and Ramachandran, Wage Labour, p. 254.

"For an example of a revisionist text which regards unfreedom as evidence of the enhanced bargaining power of agricultural labour (= worker "self-empowerment"), see Bauer, "Rural Workers", pp. 46-47, 54. A variant of this position is the postmodem view of Prakash (see below), whereby unfree workers symbolically "win" battles in the ideological domain which in economic terms they either lose or do not fight.

${ }^{12}$ It is not without significance that neoclassical economic theory, which emerged in the 1870 s, was an explicitly anti-marxist response to the development of the labour movement. In politico-ideological terms, it constituted a project of innateness, or the dehistoricizing and reconstituting as immulable of what had been regarded by classical economic theory as terrain changed by conflict; in neoclassical analysis, such terrain became an unchanging and thus a "natural" socio-economic order. 
a methodological inability and/or theoretical unwillingness to address non-economic aspects of unfreedom, and the consequent failure to problematize coercion, is the epistemological impermissibility of unfreedom within a neoclassical economic framework. Having banished coercion, neoclassical economics is left with a form of market essentialism, a reductionist approach whereby anything and everything involving the employer/worker relationship is ipso facto proof of the harmonious operation of a free (or "perfect") market in which choice-making individual labourers express subjective preferences. ${ }^{13}$

The fact that within this framework value is subjective and not objective, and consequently all parties to market exchanges receive the value of their own individual economic contribution and nothing more, necessarily precludes analytical categories such as exploitation, class formation and reproduction, and class struggle. Since neoclassical economic theory cannot accept that in some circumstances employers prefer to recruit unfree labour, and thus may actually strive to bring about an imperfect market, it correspondingly fails to recognize the attempt by either party to change the relationship from what it is to

${ }^{13}$ For the application of a neoclassical economic framework to unfree labour, see inter alia, Robert Evans, "Some Notes on Coerced Labor", Journal of Economic History, 30 (1970), pp. 861-866; W. W. Brown and M. O. Reynolds, "Debt Peonage Re-examined", Joumal of Economic History, 33 (1973), pp. 862-871; R. W. Fogel and S. L. Engerman, Time on the Cross: The Economics of American Negro Slavery (London, 1974); David Galenson, White Servitude in Colonial America (Cambridge, 1981); Robert Higgs, Competition and Coercion: Blacks in the American Economy, 1865-1914 (Cambridge, 1977); Cotlear, El sistema; R. Shlomowitz, "Markets for Indentured and Time-expired Melanesian Labour in Queensland, 1863-1906", Journal of Pacific History, 16 (1981), pp. 70-91; Bardhan, Land, Labour, pp. 61, 67, 71-72, 83-84, 86, 124-126, 157, 175; S. L. Engerman, "Servants to Slaves to Servants: Contract Labour and European Expansion", in P. C. Emmer (ed.), Colonialism and Migration: Indentured Labour Before and After Slavery (Dordrecht, 1986), pp. 263-294; N. V. Jagannathan, Informal Markets in Developing Countries (New York, 1987), pp. 38ff; T. N. Srinivasan, "On Choice among Creditors and Bonded Labour Contracts", in Pranab Bardhan (ed.), The Economic Theory of Agrarian Institutions (Oxford, 1989), pp. 203-220; Deepak Lal, The Hindu Equilibrium: II Aspects of Indian Labour (Oxford, 1989), pp. 120-126. For critiques from different theoretical viewpoints of the methods utilized in this process, see H. G. Gutman, Slavery and the Numbers Game (Chicago, 1975); Richard Sutch, "The Treatment Received by American Slaves: A Critical Review of the Evidence Presented in Time on the Cross", Explorations in Economic History, 12 (1975), pp. 335-438; P. A. David et al., Reckoning with Slavery: A Critical Study in the Quantitative History of American Negro Slavery (New York, 1976); Michael Greenberg, "The New Economic History and the Understanding of Slavery: A Methodological Critique", Dialectical Anthopology, 2 (1977), pp. 131-141; Jay R. Mandle, The Roots of Black Poverty: The Southern Plantation Economy after the Civil War (Durham, NC, 1978), pp. 22-27; Elizabeth Fox-Genovese and Eugene D. Genovese, Fruits of Merchant Capital: Slavery and Bourgeois Property in the Rise and Expansion of Capitalism (New York, 1983), pp. 91ff; Adrian Graves, "The Nature and Origins of Pacific Islands Labour Migration to Queensland", in Shula Marks and Pcler Richardson (eds), Intermational Labour Migration: Historical Perspectives (London, 1984), pp. 113115: and Brass, "Market Essentialism", pp. $225 f$. 
what in the opinion of the respective protagonists it ought to be. The absence of this crucial dimension - class struggle - in effect negates the neoclassical view of the market as an arena of harmony, and undermines not only the notion of an equilibrium structuring the exchange between employer and labourer, but also the assumption that rural employers (planters, landlords, rich peasants, labour contractors) are everywhere and always interested in the operation of a free market, and strive towards its realization.

Much the same is true of the frequently invoked "survival strategies" framework. ${ }^{14}$ In so far as it entails an "adaptive" approach by an individual choice-making subject, therefore, the concept "survival" is similarly compatible with neoclassical economic theory. Within such a framework, moreover, there is an analogous progression in textual interpretation whereby "survival" shifts rapidly from being an end in itself to being a positive countervailing aspect of the agrarian context under consideration (plantation, estate, rich peasant holding), a position which then links up with the neoclassical claim that rural workers actively chose such (unfree) employment, which consequently could have been neither exploitative nor oppressive. ${ }^{15}$ Significantly, the "survival strategies" framework is in many ways similar to the notion of "self-help" which structures much of the currently fashionable theory of peasant "resistance", itself strongly influenced by the work of James Scott. ${ }^{16}$ Where resistance occurred on the plantation or estate system, the argument goes, then the unfree relations of production structuring its labour process were consequently rendered unviable; from this position it is once again a short step to the neoclassical economic argument that, as workers could have made it non-operational had they chosen so to do, the continued existence in such contexts of unfreedom was ipso facto chosen by the workers themselves, hence non-coercive, non-exploitative and to their advantage.

Even some variants of marxism also overlook the fact that unfreedom is constructed and undermined by class struggle. Ironically, attempts by neoclassical theory to combat negative portrayals of black slaves on the

"See, for example, G. K. Lieten, O. Nieuwenhuys and L. Schenk-Sandbergen, Women, Migrants and Tribals: Survival Strategies in Asia (New Delhi, 1989).

15 For just such a positive theorization of "survival" by female indentured labour on plantations in Fiji, see B. V. Lal, "Kunti's Cry: Indentured Women on Fiji Plantations", in J. Krishnamurty (ed.), Women in Colonial India: Essays on Survival, Work and the State (Delhi, 1989), p. 179.

"For more recent examples of the ubiquitous "resistance" theory, see James C. Scott, Weapons of the Weak: Everyday Forms of Peasant Resistance (New Haven, 1985), Forrest D. Colbum (ed.), Everjday Forms of Peasant Resistance (New York, 1989), and Douglas Haynes and Gyan Prakash (eds), Resistance and Everyday Social Relations in South Asia (Delhi, 1991). For the application by Scott of his "resistance" framework to chattel slavery, see "Domination, Acting, and Fantasy", in Carolyn Nordstrom and JoAnn Martin (eds), The Paths to Domination, Resistance, and Terror (Berkeley, 1992), pp. 55-84. 
cotton plantations of the antebellum American South through arguments about "positive" aspects of black economic participation and autonomy in the plantation system (material well-being, self-improvement, etc.) find parallels in attempts by left scholars similarly to challenge negative stereotypes by invoking positive images of a resilient black culture produced by plantation slaves themselves. ${ }^{17}$ The difficulty faced by both these politically opposed viewpoints is that they license a discursive slide whereby the defence of blacks (implicitly or explicitly) may ultimately - as the case of Fogel and Engerman demonstrates - be transformed into a celebration of the plantation, and in particular its mode of unfreedom. This in turn opens up a theoretical space for anti-universalizing/decentered postmodern analysis: the latter objects to (and thus denies the efficacy and existence of) unfreedom on the grounds that, in the overarching meta-narratives of colonial and capitalist discourse, free labour is privileged as the totalizing agent of universal progress. Like neoclassical economic theory, which precludes a connection between capitalism and unfreedom by redefining the latter as free wage labour, postmodernism dismisses bondage as a figment of Western discourse, thereby banishing it from indigenous accumulation and simultaneously reifying unfreedom as a cultural "other".

In the postmodern framework of Taussig, for example, the debt peonage relation encountered in the Putumayo region of Peru during the Upper Amazon rubber boom of the early 1900s merges into and becomes nothing more than a specifically cultural manifestation of irreducible "otherness"/difference; accordingly, unfreedom possesses only a discursive existence, linked to the construction by colonists of a mythological, folkloric image of indigenous horror/terror (based on savagery, rebelliousness and/or cannibalism), and projected by them on to the tribal workforce they recruited and employed. ${ }^{18}$ Rather than connecting the existence of terror/unfreedom in such a context to struggles over the commodification of labour-power, and identifying

${ }^{17}$ For the economic self-improvement and achievement of black slaves on the plantation in the American South, see Fogel and Engerman, Time on the Cross, pp. 108-109, 127. For examples from the other end of the political spectrum of a "culturalist" defence of slaves (not slavery), see C. L. R. James, Spheres of Existence (London, 1980), pp. 173190; and Eugene Genovese, Roll, Jordan, Roll: The World the Slaves Made (London, 1975). In part, the defence of slave economic life on the plantation by those on the political right and of slave culture by those on the political left were both attempts to rescue black slaves from the negative image associated with the passive, docile "sambo" stereotype projected by Stanley Elkins, Slavery: A Problem in American Institutional and Intellectual Life (Chicago, 1959).

18 Michael Taussig, "Culture of Terror - Space of Death; Roger Casement's Putumayo Report and the Explanation of Torture", Comparative Studies in Society and History, 26 (1984), pp. 467-497; Michael Taussig, Shamanism, Colonialism, and the Wild Man (Chicago, 1987). 
thereby a specifically economic role for terror in the enforcement of unfreedom which in turn licenses the process of capital accumulation, he deprivileges/banishes economics and reifies ideology. ${ }^{19}$

Unsurprisingly, Taussig opts instead for the non-economic, innateness of Foucault's postmodern concept of power, whereby the exercise of terror becomes an irrational end in itself; in short, a Nietzschean view of terror/unfreedom as chaotic, purposeless, and hence unchanging and unchangeable. ${ }^{20}$ The resulting analysis oscillates uneasily between two competing discourses about debt peonage in the Upper Amazon region: one by Roger Casement condemning the use of unfree labour for rubber production, the other by employers supporting its use, and (because of "epistemic murk") neither of which according to Taussig is it possible to categorize as true or false. ${ }^{21}$ Like other revisionists, Taussig comes near not just to endorsing the "lazy native" myth, but also to questioning both the actuality of terror - as distinct from the efficacy of discourse about this (= uncorroborated "stories" which are believed, and thus possess a materiality regardless of whether or not they are accurate) - and ultimately the reasons for together with the existence of debt peonage itself. ${ }^{22}$

19 At some points Taussig maintains that in the Upper Amazon region a market for labour-power was absent, and is therefore correspondingly dismissive of Casement's attribution of tersor/unfreedom to a scarcity of workers; elsewhere, however. Taussig appears to accept not merely the existence of labour shortages but also the economic irrationality of destroying scarce workers and that the object of terror was in fact to increase rubber production. "Culture", pp. 475-477, 488; Wild Man, pp. 46, 52ff. For Casement's account of Putumayo, see Peter Singleton-Gates and Maurice Girodias, The Black Diaries: An Account of Roger Casement's Life and Times with a Collection of his Diaries and Public Writings (London, 1959), pp. 201-315. In other words, terror combined with unfreedom possessed a twofold economic object: to intensify output on the one hand, and on the other to wam potential absconders of the consequences of fight/ disobedience. As in the case of the tobacco plantations in the Dutch colony of Sumatra, therefore, executions and floggings of tribal workers in the Putumayo region took place in the labour process itself. Jan Breman, Taming the Coolie Beast: Plantation Society and the Colonial Order in Southeast Asia (New Delhi, 1989); Taussig, "Culture", pp. 475477.

20 Ibid., pp. 491, 495; Wild Man, pp. 27, 69, 442-443.

21 "Culture", pp. 470, 494; Wild Man, pp. 27-28, 29. This equivocation on the part of Taussig is prefigured in the similarly postmodern ambiguity of de Man, who notes: "It is always possible to face up to any experience (to excuse any guilt). because the experience always exists simultaneously as fictional discourse and as empirical event and it is never possible to decide which one of the two possibilities is the right one. The indecision makes it possible to excuse the bleakest of crimes because, as a fiction, it escapes from the constraints of guilt and innocence." Paul de Man, Allegories of Reading (New Haven, 1979), p. 293. The outcome of this framework, in which language is decoupled from material reality, is ethical relativism, which in turn naturalizes horrorl terror/(unfreedom). That such a position licenses complicity with fascism is confirmed by the cases not only of de Man himself but also of Heidegger, Blanchot and Derrida.

2 For Taussig's views on the "lazy native", see "Culture", p. 490. Other revisionist endorsements of the "lazy native" myth are noted in Brass, "Revisionist Reinterpreta. 
The more recent postmodern (re-)interpretations of unfreedom by Prakash and McCreery not only attempt to give voice to the mute indigenous subject of Taussig's analysis, but in so doing push the problematic theorization of unfreedom structuring his postmodern framework to its logical conclusion. Since Taussig does not address the issue of how unfreedom was perceived "from below" by the tribal worker, for him the question of a negative/positive perception of such a relation by the subject of labour does not arise, and consequently remains open. .In seeking to answer precisely this question, and attempting to supply this missing voice-from-below, texts by both Prakash and McCreery illustrate how a postmodern and revisionist concept of unfreedom is compatible with the concepts "popular culture" and "resistance" theory. ${ }^{23}$

Like Taussig, Prakash maintains that because it lacked a discursive form in the pre-colonial era, debt bondage in the Indian state of Bihar automatically had no relational existence; he concludes that unfreedom is the significant and invented other of "colonial discourse", and consequently that freedom is the correspondingly unacceptable embodiment of totalizing Eurocentric notions of human destiny. ${ }^{24}$ Against this it is possible to make two points. First, that as with Taussig, this symptomatically postmodern outside-of-discourse/language-there-is-nothing view is a palpably idealist position. ${ }^{25}$ And second, that - again like Taussig - Prakash fails accordingly to distinguish between an ideology of unfreedom (which may indeed have been absent, although precisely what constitutes proof of this remains problematic) and de facto unfreedom, which had a material existence that predated colonialism (regardless of whether or not it was identified by its subject as such).

Notwithstanding his claim that hierarchical inversion in oral tradition was a form of "resistance" practised by unfree labour in the southern

tions", pp. 90-91. For Taussig's questioning of the actuality of terror/unfreedom, see "Culture", p. 494; Wild Man, pp. 60, 65-66.

${ }^{23}$ G. Prakash, "Bonded Labour in South Bihar: A Contestatory History", in S. Bose (ed.), South Asia and World Capitalism (Delhi, 1990), pp. 178-205; G. Prakash, Bonded Histories: Genealogies of Labor Servitude in Colonial India (Cambridge, 1990); idem, "Becoming a Bhuinya: Oral Traditions and Contested Domination in Eastern India", in Haynes and Prakash (eds), Contesting Power, pp. 145-174; and "The History and Historiography of Rural Labourers in Colonial India" and "Reproducing Inequality: Spirit Cults and Labour Relations in Colonial Eastern India", in G. Prakash (ed.), The World of the Rural Labourer in Colonial India (Delhi, 1992), pp. 1-46, 282-304.

24 Prakash, "Bonded Labour", pp. 197-198. Not the least of the many difficulties which confront the postmodern framework of Prakash is its refusal to countenance any alternative to a specifically bourgeois/individualist concept of freedom, thereby ignoring completely the socialist approach in which unfreedom is negated by collective freedom based on class.

25 For an instance of the application of an idealized"culturalist" approach to the more general question of rural labour in Colonial India, see Prakash, "History and Historiography". 
part of Bihar in eastern India, Prakash finally concedes that, after all, it might just be the case that "the resistance contained in oral traditions was not particularly significant; they may have made the burden of bondage a little easier to shoulder, moderated the impact of hierarchy, but did little to change the 'real' condition of the Bhuinyas [...] one may say that the oral traditions deluded the Bhuinyas into thinking that -they were reconstituting hierarchy and labour relations when, in fact, they did nothing of the sort." 26 In other words, what is idealized by Prakash as a form of "resistance" may amount to no more than a contextually/historically specific form of false consciousness."

Another symptomatic text in this regard is that by McCreery, where the culturally-based "resistance" theory of Scott is combined with a "survival strategy" framework in order to invert the meaning of unfreedom on coffee plantations in Guatemala during the late nineteenth century. Despite noting that "[f]orce, the coffee planters reasoned, was what the Indian understood, force would do, and force was what the Indians got", that "[1]abor recruiters and state agents in villages jailed workers, beat and defrauded them, kidnapped their wives and children, and burned their houses", that from the 1870s "the state [. . .] had the ability to deliver effective and immediate violence to the countryside", and that "[1]ife on the run and cut off from [...] the community, [...] was precarious [. . .] [Labour contractors and village authorities], pressed to deliver labor, [. . .] increasingly took their search for [workers] into every corner of the municipality, making evasion more difficult", McCreery nevertheless claims that the state was powerless to enforce unfreedom on the indigenous population..$^{28}$ For this reason, he theorizes the debt bondage relation in a positive fashion, as a mechanism that enabled rural workers "to force from their employers as much money

${ }^{26}$ Prakash, "Becoming a Bhuinya", p. 170. Much the same can be said of his attempt to inscribe "resistance" into spirit cults in south Bihar. Prakash, "Reproducing Inequality". "Part of the difficulty here is that the concept "false" consciousness is itself epistemologically impermissible within a postmodern framework. Since Prakash not merely accepts but celebrates the plurality of the ideological, by definition no form of consciousness can be categorized as "false". Generally speaking, postmodemism rejects consciousness of class as a Eurocentric concept that involves an "outsider" unaceeptably imputing a politically appropriate, logically consistent and historically necessary set of universalistic beliefs to particular socio-economic agents. However, without a concept of consciousness that discriminates between notions of "true" and "false" (which in turn entails the theorization of a politics that transcends the randomness of non-specific, amorphous conflictive practices), it becomes possible to identify each and every single component of behaviour/ activity (or existence) as yet another form of "resistance".

28 David McCreery, "Hegemony and Repression in Rural Guatemala, 1871-1914", Peasant Studies, 17 (1990), pp. 161, 164, 166, 168. For earlier, non-revisionist, accounts by the same author of unfreedom in Guatemala, see McCreery, "Debt Servitude in Rural Guatemala, 1876-1936", Hispanic American Historical Review, 63 (1983), pp. 735-759; "'An Odious Feudalism': Mandamienıo Labor and Commercial Agriculture in Guatemala, 1858-1920", Latin American Perspectives, 48 (1986), pp. 99-117. 
as possible"; accordingly, bonded labour is subsumed by McCreery under the rubric of "culture" which - along with folk tales, dances, religious ceremony and ritual - becomes yet another form of unproblematically successful "resistance" on the part of indigenous communities. ${ }^{29}$

In many ways, these different attempts to revise the meaning of unfreedom constitute a new variety of functionalism. The old functionalism of Durkheim and Parsons maintained that the survival of a particular institutional form (such as religion) was linked to its capacity to satisfy basic societal needs, thereby contributing to what was perceived as social stability; as critiques pointed out, however, this amounted to a framework in which institutions were functional-for-those-who-rule. By contrast, the new functionalism of the "survival strategies" theory and postmodernism argues that the continued existence of institutional forms such as indenture and debt bondage is similarly linked to their ability to meet basic social needs, but this time not of the subjects but rather of the objects of rule; that is, unfreedom as a relationship that is perceived as being functional-for-those-who-are-ruled.

\section{UNFREE LABOUR AND THE FEUDAL/SEMI-FEUDAL THESIS}

A major theoretical shortcoming in the revisionist thesis is the absence of a concept of agrarian class structure, and therefore class struggle. ${ }^{30}$ Unsurprisingly, this results in turn in a fundamental misrecognition concerning the reason for the presence of unfree relations. In the case of Latin America, for example, revisionists perceive bonded labour (the enganche system) as a necessary element in the formation of a labour market: however, because unfreedom is regarded as a pre-capitalist relation, and thus equated with feudalism/semi-feudalism or "refeudalization", yet because the enganche operates in the context of capitalist agriculture, it is theoretically necessary to recast the debt bondage relation as a form of free wage labour. ${ }^{31}$ Such a relationship, it is implied or asserted, was (and is) the only way in which peasants could be persuaded to sell their labour-power and so be drawn voluntarily into the process of capitalist production. Since on the one hand the element of coercion has been eliminated, and on the other primitive accumulation made possible, it now becomes feasible within the revisionist framework to argue that bonded labour represents not only an

\footnotetext{
20 McCreery, "Hegemony and Repression", pp. 167, 169, 172.

30 The reasons for this are examined more fully in Brass, "Revisionist Reinterpretations", pp. 88ff, and "Deproletarianization", pp. 37ff.

"Taylor, "Earning a Living", p. 120; and Bill Albert, "The Creation of a Proletariat on Peru's Coastal Sugar Plantations: 1880-1920", in B. Munslow and H. Finch (eds), Proletarianization in the Third World (London, 1984), pp. 109-110. For other examples of the theorization of unfree labour in Latin America as a pre-capitalist/feudalsemi-feudal relation, see Bauer, "Rural Workers", pp. 53, 61; Cotlear, El Sistema, p. 52.
} 
economically progressive tendency (signalling a transformation from feudalism to capitalism) but also constitutes a development towards or actual evidence of proletarianization. When confronted with the coexistence of unfree labour and capitalism, therefore, revisionists respond by accepting the presence of capitalism but redefine the relation of production.

Precisely the opposite procedure is followed by the variant of marxism held by proponents of the semi-feudal thesis. Similarly incapable of theorizing the connection between capitalism and unfree labour, in this case it is not the production relation but the mode of production which is redefined. Within such a framework, therefore, relations like debt bondage retain their feudal connotation: unconnected with accumulation, unfreedom is seen instead as an archaic survival through which unproductive landlords extract pre-capitalist forms of rent from smallholding peasant proprietors, sharecroppers, or estate tenants. Thus economic stagnation in India is attributed by Bhaduri, Prasad, and others to an unwillingness on the part of feudal/semi-feudal landlords to install labour displacing and productivity enhancing technological improvements because this would undermine their political hold over the indebted tenants from whom they obtain an income based on property rights and usury. ${ }^{32}$ Rather than follow the "rational" economic behaviour of capitalists who employ free labour in order to maximize output and profits, therefore, the Indian landlord class is categorized as uniformly "feudal" in so far as it prefers instead to combine low growth with the continued employment of bonded labour, a situation which blocks the development of the productive forces (and hence the expansion of capitalism) in agriculture.

There are two difficulties with this view. First, such a theorization cannot account for the continued existence or indeed the expansion of unfreedom, not just in what are undeniably areas of capitalist agriculture but also in some urban industrial capitalist contexts. The use of forced labour in Europe during wartime, the continuing existence of peonage in the United States, and contract migrant labour in white South African mining and industry and the sunbelt states in the USA, together with moves towards extra-territorial production zones (where legislation

32 Amit Bhaduri, "A Study in Agricultural Backwardness under Semi-Feudalism", The Economic Journal, 83 (1973), pp. 120-137; idem. The Economic Structure of Backward Agriculture (London, 1983); Pradhan H. Prasad, "Semi-Feudalism: The Basic Constraints of Indian Agriculture", in Arvind N. Das and V. Nilkant (eds), Agrarian Relations in India (New Delhi, 1979), pp. 33-49; Lopsided Growth: Political Economy of Indian Development (Bombay, 1989), pp. 37-43. For other instances of the unproblematic equation of unfree labour with feudalsemi-feudal relations in Indian agriculture, see, inter alia, Bardhan, Land, Labor, pp. 81-83; Breman, Peasants, Mligrants, pp. 131, 306313; S. P. Tiwary, "Bondage in Santhal Parganas", and Suneet Chopra, "Bondage in a Green Revolution Area: A Study of Brick Kiln Workers in Mluzaffernagar District", both in Patnaik and Dingwaney, Chains of Senvitude, pp. 180-181, 212. 
protecting workers does not apply), and the replacement of welfare provision with workfare, the compulsory "training"/"retraining" schemes for youth and the long-term unemployed in metropolitan capitalist countries, all point to the opposite conclusion..$^{33}$ Rather than an archaic relational form constituting an obstacle to (and therefore destined to be eliminated by) capitalism, unfree labour is in certain circumstances an integral aspect of both the initial and continuing accumulation process.

The second difficulty with the feudal/semi-feudal thesis is that, as with other apparently "innocent" forms of conceptualizing unfreedom, this lacunae (capitalism and unfreedom are incompatible) in turn opens up a theoretical space for the neoclassical economic argument that, in a capitalist context, such agrarian relations are not unfree (or bonded) but much rather free wage labour. However, it is important to note that there is no disagreement with the semi-feudal thesis as advanced by Bhaduri and Prasad regarding both the existence and the effect of the control exercised by landlords over their workers by means of the debt mechanism; the main objection is that, for them, such control is confined to and indeed indicative of feudalism/semi-feudalism. As is argued, both here and elsewhere, capitalist producers also resort to this

${ }^{33}$ For the use of forced labour by both parties to the conflicts of 1914-1918 and 19391945, see B. Ferencz, Less than Slaves: Jewish Forced Labour and the Quest for Compensation (Cambridge, Mass., 1979); M. Summerskill, China on the Western Front: Britain's Chinese Work Force in the First World War (London, 1982); L. Elsner, "Foreign Workers and Forced Labor in Germany During the First World War", in D. Hoerder (ed.), Labor Migration in the Atlantic Economies (Westport, 1985), pp. 189-222; M. Sherwood, Many Struggles: West Indian Workers and Service Personnel in Britain 1939 45 (London, 1985), pp. 93-130; Peter Hayes, Industry and Ideology: IG Farben in the Nazi Era (Cambridge, 1987); and Ulrich Herbert, A History of Foreign Labor in Germany, 1880-1980: Seasonal Workers/Forced Laborers/Guest Workers (Ann Arbor, 1990). Accounts of peonage, unfree migrant labour, and the workfare system in the USA and Canada are contained in United States Congress, Hearings on Migrant and Seasonal Farmworker Powerlessness, Part 1 (Washington, 1970), pp. 5-15, 28, 39-49, 66, 95-100, 108-111, 116-117, 122, 125-145, 158, 176ff, and Part 2 (Washington, 1970), pp. 353ff, 433-434, 450-451, 473-474; and William H. Friedland and Dorothy Nelkin, Mfigrant: Agricultural Workers in America's Northeast (New York, 1971); Pete Daniel, The Shadow of Slavery: Peonage in the South 1901-1969 (Urbana, 1972), and "The Metamorphosis of Slavery, 1865-1900", Journal of American History, 66 (No. 1, 1979), pp. 88-99; David C. Griffith, "Nonmarket Labor Processes in an Advanced Capitalist Economy", American Anthropologist, 89 (1987), pp. 838-852; Fred Block and John Noakes, "The Politics of New-style Workfare", Socialist Review, 18 (1988), pp. 31-58; Vic Satzewich, "Unfree Labour and Canadian Capitalism: The Incorporation of Polish War Veterans", Studies in Political Economy, 28 (1989), pp. 89-110. For the employment of unfree black workers in the mining and industrial sectors of white South Africa, see among (many) others, Francis Wilson, Labour in South African Gold Mines 1911-1969 (London, 1972), and Migrant Labour in South Africa (Johannesburg, 1972); Ruth First, Black Gold: The Mozambican Miner, Proletarian and Peasant (Brighton, 1983). For the existence of unfree industrial labour in the special processing zones of China, see S. Yonghong, "Export Processing Zones in China", Economic and Political Weekly, 24 (1989), pp. 355-365. 
method of workforce control/discipline in the form of deproletarianization; that is, imposing or reimposing unfreedom on workers whose sole property is their labour-power.

\section{UNFREE LABOUR, DEPROLETARIANIZATION, AND CAPITALIST RESTRUCTURING}

Generally speaking, deproletarianization (or the economic and politicoideological decommodification of labour-power) corresponds to workforce restructuring by means of introducing or reintroducing unfree relations, a process of class composition/recomposition which accompanies the struggle between capital and labour. ${ }^{34}$ In contexts/periods where and when further accumulation is blocked by overproduction, economic crisis may force capital to restructure its labour process either by replacing free workers with unfree equivalents or by converting the former into the latter. The economic advantage of deproletarianization is that such restructuring enables landholders and planters first to lower the cost of local workers by importing unfree, more easily regulated, and thus cheaper outside labour, and then to lower the cost of the latter if and when the original external/local wage differential has been eroded..$^{35}$ In this way it is possible either to maintain wages at existing

34 A common form of historical and contemporary restructuring is the decentralization of the labour process itself, a transformation which entails the displacement of existing factory production by a small scale outwork/putting-out system based on unfree sweated labour. A recent study of the clothing trade in nineteenth-century London has argued that the introduction of the sweatshop system was a result of industrial growth rather than stagnation, and suggests that the switch to production with low-paid workers in unregulated or non-unionized premises during the second half of the century was a direct response by employers to the consolidation in the first half of a well-organized, militant and highly unionized workforce protected by factory legislation: James A. Schmiechen, Sweated Industries and Sweated Labor: The London Clothing Trades 1860-1914 (London, 1984). For accounts of a similar restructuring process in the contemporary period, see Les Levidow, "Grunwick: The Social Contract meets the 20th Century Sweatshop", in L. Levidow and B. Young (eds), Science, Technology and the Labour Process (Volume 1) (London, 1981), pp. 123-171; Philip Mattera, Off the Books: The Rise of the Underground Economy (London, 1985); and Swasti Mitter, "Industrial Restructuring and Manufacturing Homework: Immigrant Women in the UK Clothing Industry", Capital \& Class, 27 (1986), pp. 37-80. The way in which unfree relations are enforced within these small-scale units is outlined by Barbro Hoel, "Contemporary Clothing 'Sweatshops', Asian Female Labour and Collective Organization", in Jackie West (ed.), Work, Women and the Labour Mfarket (London, 1982), pp. 80-98.

${ }^{35}$ Instances abound across space and time of cost cutting achieved through restructuring based on deproletarianization, albeit frequently not theorized as such. See, for example, Wal Hannington, The Problem of the Distressed Areas (London, 1937), pp. 92-114; C. B. Dew, Ironmaker to the Confederacy: Joseph $R$. Anderson and the Tredegar Iron Works (New Haven, 1966), p. 30; Hugh Tinker, A New System of Slavery: The Export of Indian Labour Overseas 1830-1920 (London, 1974), pp. 217-218; Arismendi Diaz Santana, "The Role of Haitian Braceros in Dominican Sugar Production", Latin American Perspectives, 8 (1976), pp. 120-132; Josh DeWind et al., "Contract Labor in US 
(low) levels or even to decrease pay and conditions of both components of the workforce, thereby restoring or enhancing profitability and with it the accumulation projection (or linked to) the capitalist labour process.

In ideological terms, the object of the deproletarianization/decommodification of distinct forms of labour-power employed by capital is either to prevent the emergence of a specifically proletarian consciousness or to curtail the latter where it already exists. Hence the utilization of unfree components from the industrial reserve army of labour not as an addition to the existing (free) workforce but rather as a substitute for - and thus competitors with - the latter has dire consequences for the development of working-class political consciousness, in agriculture no less than manufacturing. There are numerous instances of racist responses on the part of an existing agrarian workforce displaced by the nationally/ethnically/regionally specific labour-power of cheap, unfree migrants recruited by planters, landowners or rich peasants engaged in the restructuring of the labour process. ${ }^{36}$

Where an initially progressive proletarian class struggle shows signs of being or becoming effective, the attempt by capital to demobilize it by means of workforce restructuring may convert what is an actually or potentially revolutionary situation into a politically reactionary combination of nationalism and racism. Accordingly, in such circumstances the form taken by class struggle waged from above in turn affects the form taken by class struggle waged from below. Although it may continue to reproduce itself in economic terms, therefore, and thus constitute a (segmented) class-in-itself, working-class recomposition takes the all-important form of class-for-itself only where and when such politico-ideological division is transcended.

Agriculture: The West Indian Cane Cutters in Florida", in Robin Cohen et al. (eds), Peasants and Proletarians: The Struggles of Third World Workers (London, 1979), pp. 380-396; Michael Monteón, "The Enganche in the Chilean Nitrate Sector, 1880-1930", Latin American Perspectives, 22 (1979), p. 66; Marianne Ramesar, "Indentured Labour in Trinidad 1880-1917", in Kay Saunders (ed.), Indentured Labour in the British Empire 1834-1920 (London, 1984), pp. 60, 65; and Tom Brass, "Class Formation and Class Struggle in La Convención, Peru", Journal of Peasant Studies, 7 (1980), pp. 427-457, "Revisionist Reinterpretations", and "Class Struggle and Deproletarianisation".

${ }^{36}$ For examples of racism as a result of restructuring, again not necessarily interpreted as such, see R. W. Beachey, The British West Indies Sugar Industry in the Late Nineteenth Century (Oxford, 1957), p. 109; Tinker, A New System of Slavery, pp. 217, 218-219; Doug Hunt, "Exclusivism and Unionism: Europeans in the Queensland Sugar Industry 1900-1910", in Ann Curthoys and Andrew Markus (eds), Who Are Our Enemies? Racism and the Australian Working Class (Sydney, 1978), pp. 80-95; Cohen, The New Helots, pp. 52-53, 129-130, 187, 193ff; Roger Plant, Sugar and Modern Slavery (London, 1987), pp. 69-70; Michiel Baud, "Sugar and Unfree Labour: Reflections on Labour Control in the Dominican Republic, 1870-1935", Journal of Peasant Studies, 19 (1992), pp. 301325. 
In contrast to the position adopted here, which links the existence of unfree relations to issues of profitability and class struggle, the presence or absence of unfreedom is generally attributed simply either to a shortage or to a surplus of labour. The view that unfreedom derives from labour scarcity is linked to the work of Nieboer, who argued that as inhabitants of non-capitalist societies usually prefer to work for - themselves rather than for others, actual or potential employers of labour-power must rely on unfree workers so long as unappropriated land ("open resources") is still available. ${ }^{37}$ Once land becomes private property (or a "closed resource"), unfree labour ceases to be necessary since the sale of labour-power is now the only method of obtaining subsistence. However, the use of indenture or debt bondage against free workers already separated from means of production suggests that reasons for the existence of unfree relations are unconnected with the need of agrarian capitalists to compel unwilling and/or wholly selfsufficient peasant proprietors to sell their labour-power, and raises the issue of the connection between unfreedom and worker availability. In such circumstances, the concept "labour shortage" possesses a specific politico-ideological meaning. The term is applied by employers not to an absolute unavailability of labour-power (additional workers are needed, yet none exist) but to situations where market forces or political consciousness permit free workers to act as (and reap the benefits from being) proletarians. ${ }^{38}$

${ }^{37}$ H. J. Nieboer, Slavery as an Industrial System: Ethnological Researches (The Hague, 1910). This view also structures the argument in two recent texts, where the presence of unfree labour in Russia and on the plantation systems of America, the Caribbean, South Africa, and Australia is linked to the existence in all these contexts of labour shortages. Miles, Capitalism and Unfree Labour, pp. 205, 214; Peter Kolchin, Unfree Labor: American Slavery and Russion Serfdom (Cambridge, Mass., 1987), pp. 18, 359 ff.

38 Attributing indentured migration generally to a "distaste by free labourers to bear the non-pecuniary costs of production upon the plantations", Engerman, "Servants to Slaves". p. 277, implies that everywhere and at all times free labour was unwilling to undertake plantation work under any circumstances. Such a view overlooks the fact that planters employed unfree contract/indentured labour because locals were exercising not an absolute but rather a relative unwillingness to work, and withholding their labour-power in order to secure improvements in pay and conditions for the application of this commodity on the plantation itself. In other words, the object of employing unfree labour in such circumstances was to compel free locals to accept plantation work conditions and pay levels that they would otherwise have rejected. For an excellent case study of the latter process, see Walter Rodney, A History of the Guyanese Working People, 1881-1905 (London, 1981). Much the same kind of restructuring procedure was operated by agribusiness enterprises in the United States during the $1960 \mathrm{~s}$, when unfree contract labour from the Caribbean was (and continues to be) imported specifically with the object of forcing local workers to accept lower wages and less favourable conditions. About this situation the normally conservative US Congress has commented: "Growers [...] have convinced the US Department of Labour that a shortage of domestic farmworkers exists and thus offshore workers are needed. We see very little evidence of such a shortage but rather that the introduction of [unfree migrant] offshore workers has greally hampered the domestic workers and in some cases has resulted in forcign workers 
The opposing view links the occurrence of unfree relations to a surfeit of agricultural labour that has few or no alternative sources of subsistence. Many texts on rural labour in India are structured by this argument, unfree relations being seen as connected with the existence at different historical periods of labour surpluses in agriculture.$^{39}$ Both past and present forms of bondage are theorized as the result of economic immizeration that afflicted large sections of the rural workforce; accordingly, unfreedom is regarded as possessing its origin not in proletarianization but in peasant impoverishment which derives from high levels of unemployment. This situation is attributed in turn to demographic growth combined with a lack of industrialization and thus non-agricultural job opportunities.

It is important to note that workforce restructuring can occur in contexts where no actual labour shortage exists, or even where surplus labour is present, as well as in those where labour is scarce. In the latter case, employers will be faced with increasing labour costs because, though not organized on a collective basis, workers are nevertheless aware of the fact that labour-power is much sought after, and attempt to sell this to the highest bidder. However, even in areas where the demand for labour is either met or exceeded by the existing supply, and consequently there is no competition for workers, employers may still be faced with rising labour costs: due to the levels of political consciousness and organization exhibited by workers on the one hand, and on the other because overproduction and the tendency of the rate of profit to fall in the course of capitalist competition generally requires individual producers to cut the price of labour-power. Despite the differences in terms of labour availability, therefore, employer response is in both cases the same: the restructuring of the labour process.

\section{CONCLUSION}

What is significant about each of the apparently distinct views considered above is that, in their different ways, all deny the possibility of a link

displacing US workers in [. . .] this country. With the foreign workers' arrival, harvesting prices for US labor dropped. As a stable supply of labor was introduced, employers refused to negotiate prices to be paid to US laborers." Unlike local workers, who can negotiate for higher wages, foreign contract workers have to accept pay levels and conditions imposed by employers, who accordingly "find it much less expensive with a controlled labor force". United States Congress, Hearings, Part 1, pp. 178, 185.

39 See, for example, Kumar, Land and Casle; Patnaik, "Introduction", pp. 9, 11ff; Utsa Patnaik, "The Agrarian Question and the Development of Capitalism in India", Economic and Political Weekly, 21 (1986), pp. 781-793; and Ramachandran, Wage Labour, pp. 258259. For a critique of the argument which unproblematically links unfreedom to population density in the case of the Caribbean, see 0 . Nigel Bolland, "Systems of Domination after Slavery: The Control of Land and Labor in the British West Indies after 1838". Comparative Sudies in Society and History, 23 (1981), pp. 591-619. 
between unfree labour and capitalism. By redefining bondage/indenture as free wage labour, therefore, both neoclassical economic theory and the revisionist variants influenced by it dismiss the existence of a connection between unfreedom and capitalism; by categorizing bondage as a figment of Western discourse, postmodern theory also rejects such a link, which by its very nature is necessarily precluded from the semi-feudal thesis. By contrast, it is maintained here that when labour begins to act individually or to organize collectively in defence of its own interests, by exercising freedom of movement to secure higher wages, better working conditions, shorter working hours, etc., capitalist employers introduce or reintroduce restrictions on the formation or extension of a labour market with the object of shifting the balance of workplace power in their own direction. This procedure corresponds to a restructuring of the labour process, and entails either replacing free workers with unfree equivalents or converting the former into the latter. In short, a socio-economic and politico-ideological transformation which amounts not to proletarianization or to depeasantization but to deproletarianization. 